\title{
Prescription pattern study of antiasthmatics drugs in tertiary care centre
}

\author{
Ujwala P. Gawali*, Parmeshwar B. Gholve, Salman H. Rizvi, Prashant S. Mishra
}

Department of Pharmacology, Dr. VMGMC, Solapur, Maharashtra, India

Received: 20 January 2021

Revised: 02 March 2021

Accepted: 03 March 2021

\section{*Correspondence:}

Dr. Ujwala P. Gawali,

Email: ujwalagawali1963@gmail.com

Copyright: (C) the author(s), publisher and licensee Medip Academy. This is an open-access article distributed under the terms of the Creative Commons Attribution Non-Commercial License, which permits unrestricted non-commercial use, distribution, and reproduction in any medium, provided the original work is properly cited.

\begin{abstract}
Background: Bronchial asthma is a social and economic healthcare burden. Drug Utilization studies can play a key role in helping the healthcare system to understand, interpret and improve the prescribing administration \& use of medications.

Methods: A prospective, Cross-sectional, Observational study was conducted at inpatient and outpatient Department of Medicine and Paediatrics in tertiary health care centre. As per inclusion criteria, 127 patients with asthma were interviewed, and prescription data was recorded in a pre-designed case record form from 1 October 2018 to 31 December 2018.

Results: A total of 127 prescriptions were studied. It was observed that majority of the study patients were in the age group of 40-50 years, with 83 (65.5\%) males and 44 (34.6\%) females. Most of the patients were of Mild intermittent asthma $65(51.18 \%)$ followed by patients with Mild persistent asthma 31 (24.40\%). 10 different anti-asthmatics drugs were prescribed along with adjunctive medicines. Most of the patients received multiple drug therapy $98(77.16 \%)$. Prevalence of two drug combination was the highest 74 (58.26 \%) followed by monotherapy29 (22.83\%). Most common route of drug administration was inhalational route followed by oral route. $\beta 2$ agonists and corticosteroids were the most commonly prescribed combination drugs followed by methylxanthines. $103(81.10 \%)$ prescription contains both generic and brand drugs compared to generic names only $16(12.59 \%)$ and brand names only $8(6.29 \%)$. Conclusions: This study concluded that the present prescribing practice in asthma therapy in tertiary care centre is not sufficiently rational. Hence, it is necessary to encourage physicians to follow asthma guidelines while managing asthmatic patients.
\end{abstract}

Keywords: Prescription pattern, Brochial asthma, Beta-2 agonist, Corticosteroids

\section{INTRODUCTION}

Asthma is a heterogeneous disease, generally it presents with chronic airway inflammatory condition. It is characterized by respiratory symptoms such as wheezing, shortness of breath, tightness of chest and cough that vary over time and in intensity. ${ }^{1}$ Epidemiologically, it is considered as 14th most important disorder in terms of extent and duration of disability. ${ }^{2}$ More than 150 million people worldwide are affected by asthma and causes 180,000 deaths annually. ${ }^{3}$ In India, prevalence of asthma in adults range from $3-11 \%$ whereas 3 to $5 \%$ pediatric population is affected by asthma. ${ }^{4}$

Contraction of bronchial smooth muscles, airway remodeling, edema and increased secretion of mucus are important contributory factors that significantly causes bronchial obstruction in asthma. Various inflammatory cells are involved in the pathgological process such as 
eosinophils, T-cells, mast cells, basophils, and neutrophils. ${ }^{5}$

Diagnosis of asthma is usually based on the presentation of symptoms, course of disease, and pulmonary function test. ${ }^{6}$ Generally its management requires long -term treatment; because of which its cost increases and due to long term management patient's compliance plays a very important role.?

Global Initiative for Asthma (GINA) guidelines suggest drugs of different classes for the management of asthma that includes long and short acting beta2 agonist (salbutamol, salmeterol, formetorol), corticosteroids (fluticasone, prednisolone, bedesonide), xanthine derivatives (theophylline) and leukotriene receptor antagonist (montelukast). These drugs are either used alone or in combinations depending upon the severity of the disease. ${ }^{8}$

As per WHO, more than half of all drugs are prescribed and dispensed inappropriately. Irrational use of medicines is a major problem observed worldwide. This inappropriate use of medicines may results in wastage of scarce resources and may cause widespread health threat. ${ }^{9}$ Screening of prescriptions and evaluation of drug utilization helps to identify the issues regarding drug use and provide useful information about current prescription patterns and shows the flaws in the current prescription practice. This also provides contributory feedback to prescribers about irrational drug use and helps to create awareness among them. ${ }^{10}$ The present study aimed to analyze prescription pattern of anti-asthmatic drugs in adherence to WHO guidelines in a tertiary care hospital.

\section{METHODS}

This prospective, cross-sectional, observational study was conducted at inpatient and outpatient Department of Medicine and Paediatrics in tertiary health care centre. The permission from Institutional Review Board was taken and verbal consent was obtained from the patients before enrolling in this study.

One hundred twenty seven (127) patients who co-operated were interviewed and information was filled in Case record form for a period of three month. (October 2018 to December 2018).

Data was collected in case record form for demographic information, diagnosis, drug history, smoking history, drugs prescribed for asthma along with their name; dose; dosage strength; route of administration; frequency of administration; and duration of therapy, investigations related to diagnosis or monitoring of therapy if mentioned, and adverse drug reaction, if any. Data were analyzed for demographic variables, proportions of patients having positive history of smoking/allergy, average number of anti-asthmatic drugs per prescription, fixed dose combinations, and generic/brand names, proportion of formulations utilized, percentage of drugs prescribed from an Essential Medicine List, proportion of irrational prescription and adverse drug reactions.

\section{Inclusion and exclusion criteria}

Patients of either gender suffering from only asthma were included in the study. Asthmatic patients who suffered from other diseases such as hypertension, heart problem, acute bronchitis, chronic bronchitis, pneumonia and other problems such as peptic ulcer, diabetes mellitus and migraine were excluded from study.

Pregnant and lactating womens were also excluded.

\section{Analysis of data}

Compilation of following data was done in the software and data was classified in different independent variable. The data was tabulated and percentage was calculated using Microsoft excel- 2013 in the computer.

\section{RESULTS}

Total 127 prescriptions of asthma patients diagnosed with asthma in the inpatients and outpatients Medicine and Pediatrics department of tertiary care hospital from 1 October 2018 to 31 December 2018 were evaluated.

Table 1: Demographic distribution of asthmatic patients.

\begin{tabular}{|llll|}
\hline $\begin{array}{l}\text { Age groups } \\
\text { (years) }\end{array}$ & $\begin{array}{l}\text { Male } \\
(\mathbf{n = 8 3})\end{array}$ & $\begin{array}{l}\text { Female } \\
(\mathbf{n = 4 4})\end{array}$ & $\begin{array}{l}\text { Total 127 } \\
(\%)\end{array}$ \\
\hline $\mathbf{0 - 1 0}$ & 03 & 01 & $04(03.14)$ \\
\hline $\mathbf{1 0 - 2 0}$ & 08 & 03 & $11(08.66)$ \\
\hline $\mathbf{2 0 - 3 0}$ & 09 & 05 & $14(11.02)$ \\
\hline $\mathbf{3 0 - 4 0}$ & 11 & 08 & $19(14.96)$ \\
\hline $\mathbf{4 0 - 5 0}$ & 32 & 17 & $48(37.79)$ \\
\hline $\mathbf{5 0 - 6 0}$ & 17 & 09 & $26(20.47)$ \\
\hline $\mathbf{> 6 0}$ & 03 & 01 & $04(03.14)$ \\
\hline
\end{tabular}

Table 2: Percentage of types of asthma patient at tertiary care center.

\begin{tabular}{|l|l|}
\hline $\begin{array}{l}\text { Types of Asthma } \\
\text { patients }\end{array}$ & $\%$ of Asthma patients \\
\hline $\begin{array}{l}\text { Mild } \\
\text { Intermittent }\end{array}$ & $65(51.18)$ \\
\hline $\begin{array}{l}\text { Mild } \\
\text { Persistent }\end{array}$ & $31(24.40)$ \\
\hline $\begin{array}{l}\text { Moderate } \\
\text { Persistent }\end{array}$ & $17(13.38)$ \\
\hline $\begin{array}{l}\text { Severe } \\
\text { Persistent }\end{array}$ & $12(09.44)$ \\
\hline $\begin{array}{l}\text { Very severe } \\
\text { Persistent }\end{array}$ & $02(01.57)$ \\
\hline
\end{tabular}


Majority of the patients were in the age group of 40-50 years.83 $(65.5 \%)$ prescriptions were of male patients and $44(34.6 \%)$ of female patients. Male patients in inpatient department were 7 and female patients were 2. About four per cent of females and six per cent of the males had a family history of asthma. Smoking history was noted positive in $11(8.66 \%)$ prescriptions. History of drug therapy for tuberculosis was mentioned in 5 (3.93\%) prescriptions. History of allergic reaction was mentioned in a $4(3.14 \%)$ prescription.

Table 3: Drugs used primarily in asthmatic patients in tertiary care hospital.

\begin{tabular}{|c|c|}
\hline Category & Name of the drugs \\
\hline$\beta$-agonist & $\begin{array}{l}\text { Salbutamol, Terbutaline, } \\
\text { Salmeterol, Formeterol }\end{array}$ \\
\hline Methylxanthine & Deriphyllin \\
\hline Corticosteroids & $\begin{array}{l}\text { Beclomethasone, Budesonide, } \\
\text { Hydrocortisone }\end{array}$ \\
\hline Anticholinergics & Ipratropium bromide \\
\hline $\begin{array}{l}\text { Leukotriene } \\
\text { antagonist }\end{array}$ & Montelukast \\
\hline Anti-histaminics & $\begin{array}{l}\text { Loratadine, Chlorpheniramine, } \\
\text { cetirizine }\end{array}$ \\
\hline
\end{tabular}

Table 4: Prescription pattern at tertiary care center.

\begin{tabular}{|lll|}
\hline Drugs & $\begin{array}{l}\text { Route of } \\
\text { administration }\end{array}$ & $\begin{array}{l}\text { Number of } \\
\text { prescriptions }\end{array}$ \\
\hline Salbutamol & $\begin{array}{l}\text { Oral } \\
\text { Inhalation } \\
\text { Oral+inhalation }\end{array}$ & 16 \\
& 02 \\
\hline $\begin{array}{l}\text { Salbutamol+ } \\
\text { Steriod } \\
\text { Combination }\end{array}$ & Inhalation & 32 \\
\hline $\begin{array}{l}\text { Formeterol+ } \\
\text { Steriod } \\
\text { Combination }\end{array}$ & Inhalation & 41 \\
\hline $\begin{array}{l}\text { Salmeterol+ } \\
\text { steroid } \\
\text { Combination }\end{array}$ & Inhalation & 10 \\
\hline $\begin{array}{l}\text { Ipratropium } \\
\text { bromide+ } \\
\text { salbutamol }\end{array}$ & Inhalation & 09 \\
\hline $\begin{array}{l}\text { Deriphyllin } \\
\text { Beclomethasone }\end{array}$ & Oral & \\
\hline Inhalation & 07 \\
\hline Hydrocortisone & Inhalation & 05 \\
\hline
\end{tabular}

The results of this study showed that most of the patients were of Mild intermittent asthma $65(51.18 \%)$ followed by patients with Mild persistent asthma $31(24.40 \%)$. Patients with very severe persistent asthma $02(1.57 \%)$ were present in inpatient medicine department.

The results of this study showed that 10 different antiasthmatics drugs were prescribed along with adjunctive medicines.
Table 5: Single/multiple drug regimen.

\begin{tabular}{|l|l|}
\hline Drug therapy & Number of patients $(\%)$ \\
\hline Single drug & $29(22.83)$ \\
\hline Multiple drug & $98(77.16)$ \\
\hline Two drug & $74(58.26)$ \\
\hline Three drug & $15(11.81)$ \\
\hline Four drug & $09(07.08)$ \\
\hline
\end{tabular}

Table 6: Percentage of prescription with generic/brand names.

\begin{tabular}{|ll|}
\hline Prescription names & Prescription $(\%)$ \\
\hline Generic names & $16(12.59)$ \\
\hline Brand names & $8(6.29)$ \\
\hline $\begin{array}{l}\text { Generic names + Brand } \\
\text { names }\end{array}$ & $103(81.10)$ \\
\hline
\end{tabular}

Among anti-asthmatics, 7 drugs were given by inhalational route, 3 drugs by oral route, 1 drug by Intravenous route and 1 drug by inhalational and oral route of administration.

Most of the patients received multiple drug therapy compared to single drug therapy. In multiple drug therapy, two-drug combinations were more widely prescribed than combinations of three/four drugs. The pattern of drug prescription in asthmatics showed the highest prevalence of $\beta$-agonist followed by corticosteroids and methylxanthine. Total 320 drugs were prescribed in 127 prescriptions. Average number of anti-asthmatic drugs per prescription was 2.5 .

Anti- histaminics were the least prescribed anti- asthmatic drug and is mostly given in tablet form. 02 (1.57\%) Very severe persistent asthmatic patients admitted were on Intravenous Hydrocortisone along with Beta agonist+ anticholinergic in inhalational form. 103 (81.10 \%) prescription were containing both generic and brand drugs whereas $16(12.59 \%)$ prescriptions were with only generic names and $8(6.29 \%)$ were with only brand names. (Table 6)

All anti-asthmatics drugs prescribed were from essential drug list provided by WHO.

\section{DISCUSSION}

Prescription audit is one of the scientific method to evaluate the rationality of the prescriptions. ${ }^{4}$ Recommendations of various international bodies on asthma are now available for the physicians which will help to improve prescribing practices and ultimately clinical standard. ${ }^{11-12}$

Rational use of drug requires that patient receive medications appropriate to their clinical needs in doses that meet their own requirements for adequate period of time and cost effective. ${ }^{13}$ Total 127 prescriptions were evaluated in this study at tertiary care centre. Demographic 
characteristics showed that males were suffering more from asthma than females, which was also observed similarly in other studies. Majority of the patients were in the age group of 40-50 years. ${ }^{4,14}$ History of smoking and allergic reactions was not mentioned on most of the prescriptions.

Out of 127 patients most of the patients were with Mild intermittent asthma $65(51.18 \%)$ and only 2 admitted were with very severe persistent asthma $02(01.57 \%)$. Overall drug prescription patterns showed that $\beta$-agonist were the drugs of choice for asthmatic patients. Similar findings were reported by Kumar et al and Srivastava et al. ${ }^{15-16}$

According to guidelines, inhaled drugs should be the first choice of drug. Majority patients received inhaled beta agonist and steroid combinations for the treatment of asthma. The inhalational route delivers more drugs locally in the respiratory tract with less side effects. The dose of drug used by inhalational route is also less. ${ }^{17}$ Use of beta agonist and steroid relieves as well as controls the symptoms of asthma. Only 2 admitted patients received systemic steroid therapy.

Corticosteroids were used in asthma management as monotherapy and combination therapy. Because of potential adverse effects associated with corticosteroids, their use was restricted as compared to $\beta$-agonists. This indicated awareness among prescribers. ${ }^{18} 16 \%$ of prescriptions were having generic names only. Being tertiary care teaching hospital, use of generic name should be promoted.

Adverse drug reactions were not documented in single prescriptions. Drugs were prescribed from an essential medicine list. Use of short forms of drugs, missing doses, frequency of administration and duration of therapy are the common problems during writing a prescription.

\section{CONCLUSION}

This study concluded that the present prescribing practice in asthma therapy in tertiary care centre is not sufficiently rational. Prescribing pattern of asthma shows more use of anti-asthmatic drugs. Standard treatment guideline should be followed. There is need to encourage physicians to follow asthma guidelines while managing asthmatic patients. In conclusion, National Asthma Education Program will be beneficial in improving asthma knowledge and increasing awareness in the medical community, on current therapy. Prescribers should be made aware to write generic names and note down the ADRs in prescription of the patient. However, shorter duration and small sample size are some of the limitations of our present study. In developing country like India, as such more systematic studies are required that can cater individual needs of patients.

\section{ACKNOWLEDGEMENTS}

Authors would like to thank the Faculty for the support.

Funding: No funding sources

Conflict of interest: None declared

Ethical approval: The study was approved by the Institutional Ethics Committee

\section{REFERENCES}

1. Global initiative for asthma. Global Strategy for Asthma Management and Prevention, 2017. Available from: www.ginasthma.org. Last accessed on

2. Lai CKW, Beasley R, Crane J, Foliaki S, Shah J, Weiland S, et al. Global variation in the prevalence and severity of asthma symptoms: phase three of the International Study of Asthma and Allergies in Childhood (ISAAC). Thorax. 2009;64(6):476-83.

3. Rafeeq MM, Murad H. Evaluation of drug utilization pattern for patients of bronchial asthma in a government hospital of Saudi Arabia. Niger J Clin Pract. 2017;20(9):1098-1105.

4. Pandey A, Tripathi P, Pandey RD. Prescription pattern in asthma therapy at Gorakhpur hospitals. Lung India. 2010;27(1):8-10.

5. Fernandes L, Henry PJ, Goldie RG. $\beta$-Adrenoceptor Agonists. In: Page CP, Barnes PJ, editors. Handbook of Experimental Pharmacology. Berlin: Springer. 2004;4-35.

6. Yawn BP. Factors accounting for asthma variability: achieving optimal symptom control for individual patients. Prim Care Respir J. 2008;17(3):138-47.

7. D.P. Pinal, R.K. Patel, N.J. Patel, Analysis of prescription pattern and drug utilization in asthma therapy, IRJP. 2012;7(3):257-260.

8. Sun HL, Kao KH, Chou MC, Lu TH, Lue KH. Differences in the prescription patterns of antiasthmatic medications for children by paediatricians, family physicians and physicians of other specialties. J Formos Med Assoc. 2006;105(6):277-283.

9. Jain S, Upadhyaya P, Goyal J. A systematic review of prescription pattern monitoring studies and their effectiveness in promoting rational use of medicines. Perspect Clin Res. 2015;6(2):86-90.

10. Db J, Vijay P, Yakaiah V, Ambadasu B. A Prospective Study on Prescription Pattern in Chronic Obstructive Pulmonary Disease. Maedica (Bucur). 2020;15(1):3744.

11. National Heart, Lung, and Blood Institute, National Institutes of Health. International Consensus Report on the Diagnosis and Treatment of Asthma. Bethesda: National Heart, Lung, and Blood Institute, National Institutes of Health. 1992;92-3091.

12. National Heart Lung and Blood institute and WHO Global Strategy for Asthma management and prevention. NHLBI/WHO workshop. NIH Publication no. 974051, Bethesda M D.USA: 1997. 
13. Ungar WJ, Coyte PC. Prospective study of the patient level cost of asthma care in children. Pediatr Pulmonol. 2001;32:101-8.

14. Shimpi RD, Salunkhe PS, Bavaskar SR, Laddha GP, Kalam A, Patel KH. Drug utilization evaluation and prescription monitoring In asthmatic patients. Int $\mathrm{J}$ Pharm Biolog Sci. 2012;2:117-22.

15. Kumar A, Tiwari HK, Kulkarni SK. Drug utilization assessment in asthma therapy through prescription monitoring. IJHP. 2004;41:70-2.

16. Srivastava R, Sharma S, Keshri L, Wal P. Assessment of prescription pattern in asthma therapy at Shamli hospitals. Rev Recent Clin Trials. 2012;7(2):158-64.
17. NIH. Guidelines for the Diagnosis and Management of Asthma. Bethesda: National Institutes of Health (NIH). 1997;41:4051-4097.

18. Ip M, Lam K, Kung A, Ng M. Decreased bone mineral density in premenopausal asthma patients receiving long-term inhaled steroids. Chest. 1994;105:1722-7.

Cite this article as: Gawali UP, Gholve PB, Rizvi SH, Mishra PS. Prescription pattern study of antiasthmatics drugs in tertiary care centre. Int $\mathbf{J}$ Basic Clin Pharmacol 2021;10:429-33. 